F.A. López, M.I. Martín, F.J. Alguacil, J.Ma. Rincón, T.A. Centeno, M. Romero. Thermolysis of fibreglass polyester composite and reutilisation of the glass fibre residue to obtain a glass-ceramic material.

Journal of Analytical and Applied Pyrolysis, 93 (2012) 104-112; DOI: 10.1016/j.jaap.2011.10.003

\title{
THERMOLYSIS OF FIBREGLASS POLYESTER COMPOSITE AND REUTILISATION OF THE GLASS FIBRE RESIDUE TO OBTAIN A GLASS- CERAMIC MATERIAL
}

\author{
F.A. López ${ }^{1}$, M.I. Martín ${ }^{2}$, F.J. Alguacil ${ }^{1}$, J. Ma. Rincón ${ }^{2}$, T.A. Centeno ${ }^{3}$ and M. Romero ${ }^{2}$
}

${ }^{1}$ Centro Nacional de Investigaciones Metalúrgicas (CENIM), CSIC, Avda. Gregorio del Amo 8, 28040 Madrid, Spain.

${ }^{2}$ Instituto de Ciencias de la Construcción Eduardo Torroja (IETCC), CSIC, Serrano Galvache 4, 28033 Madrid, Spain.

${ }^{3}$ Instituto Nacional del Carbón (INCAR), CSIC, Apartado 73, 33080 Oviedo, Spain.

\begin{abstract}
This study reports the feasibility of reusing glass fibre waste resulting from the thermolysis of polyester fibreglass (PFG) to produce a glass-ceramic material. PFG was treated at $550^{\circ} \mathrm{C}$ for $3 \mathrm{~h}$ in a $9.6 \mathrm{dm}^{3}$ thermolytic reactor. This process yielded a solid residue ( $\left.\approx 68 \mathrm{wt} . \%\right)$, an oil ( $\approx 24$ wt.\%) and a gas $(\approx 8$ wt.\%). The oil was mainly composed of aromatic $(\approx 84 \%)$ and oxygenated compounds $(\approx 16 \%)$ and had a fairly high gross calorific value $\left(\approx 34 \mathrm{MJ} \mathrm{kg}^{-1}\right)$. The major PFG degradation products were styrene, toluene, ethylbenzene, $\alpha$-methyl styrene, 3 -butynyl benzene, benzoic acid and 1,2-benzenedicarboxylic acid anhydride. The gas contained basically $\mathrm{CO}_{2}$ and $\mathrm{CO}$; the hydrocarbon content was below $10 \mathrm{vol} \%$. The higher gross calorific value of the gas was low $\left(26 \mathrm{MJ} \mathrm{Nm}^{-3}\right.$ ). The solid residue ( $97 \mathrm{wt} \%$ fibreglass, $3 \mathrm{wt} \%$ char) was converted into a glass-ceramic material. For this, a mixture consisting of $95 \mathrm{wt} \%$ of this solid residue and $5 \%$ $\mathrm{Na}_{2} \mathrm{O}$ was melted at $1450^{\circ} \mathrm{C}$ to obtain a glass frit. A powder glass sample $(<63 \mu \mathrm{m})$ was then sintered and crystallized at $1013^{\circ} \mathrm{C}$, leading to the formation of a glass-ceramic material composed of wollastonite and plagioclase s.s. with possible building applications.
\end{abstract}

Keywords: Thermolysis; Polyester fibreglass; Glass fibre; Vitrification; Glass-ceramic material 
F.A. López, M.I. Martín, F.J. Alguacil, J.Ma. Rincón, T.A. Centeno, M. Romero. Thermolysis of fibreglass polyester composite and reutilisation of the glass fibre residue to obtain a glass-ceramic material.

Journal of Analytical and Applied Pyrolysis, 93 (2012) 104-112; DOI: 10.1016/j.jaap.2011.10.003

\section{Introduction}

Fibreglass is the most commonly used reinforcement in the manufacture of composite materials with polymeric matrices. The matrix of fibreglass is composed of organic, thermostable polyester, vinylester, phenolic and epoxy resins. Polyester resins, which are essentially bisphenolic and ortho- or isophtalic, make up some $75 \%$ of this matrix.

Fibreglass reinforced plastics (FGRP) have important applications in the fields of automobile manufacturing, aeronautical industry, and in civil, mechanical and biomechanical engineering. Their properties compare favourably with those of other materials and they are sometimes used on an exclusive basis. In 2010, the total production of FGRP materials in Europe reached 1015 Mt [1].

Recycling composites is difficult since they typically contain two or more components (filler, fibre, resin, etc.). Recycling thermoset composites is a particular challenge since, once the thermoset matrix molecules are cross-linked, the resulting material can no longer be remelted or remoulded [2]. Further, the most common thermosetting resins, such as polyester and epoxy resin, cannot be depolymerised to their original constituents [3]. Thermoset composites therefore commonly end up in landfills, and since the components are non-biodegradable, the economic costs of such disposal can be very high.

A number of technologies have been proposed for recycling thermoset composites. Basically, these can be classified into three categories:

a) Mechanical comminution-based processes to obtain a specific grain size that renders the material useful as a reinforcement in new formulations [4-6].

b) Thermal processing such as:

(i) Combustion and the use of the heat generated [7-8]. The combustion of fibreglass composite waste in a cement kiln is one option. The thermosetting resin acts as fuel within the kiln, while the glass reinforcement and mineral fillers are incorporated into the cement as valid raw materials [9-10].

(ii) Pyrolysis i.e., the chemical decomposition of the organic matter by heating at moderate temperature in the absence of oxygen. Such processes produce a fuel gas which can be used for heating the pyrolysis chamber itself. It also generates certain liquid oil products and a solid residue comprised of inorganic fibres, filler and char [11-14]. Thermolysis, a 
F.A. López, M.I. Martín, F.J. Alguacil, J.Ma. Rincón, T.A. Centeno, M. Romero. Thermolysis of fibreglass polyester composite and reutilisation of the glass fibre residue to obtain a glass-ceramic material.

Journal of Analytical and Applied Pyrolysis, 93 (2012) 104-112; DOI: 10.1016/j.jaap.2011.10.003

type of pyrolysis involving the thermal decomposition of organic materials at moderate temperatures in a 3-7\% oxygen atmosphere (insufficient to allow combustion), has been successfully used to recycle scrap tyres [15].

(iii) Fluidised bed thermal processes to recover the carbon fibre reinforcement from composites [16-19].

c) Composite depolymerisation based on chemical processes such as hydrolysis, glycolysis and solvolysis to recover organic materials [20-22].

Unfortunately, the glass fibres obtained as a solid residue in pyrolysis suffer the degradation of their physical properties, limiting their reuse. Pickering [3] and Pickering et al. [17] reported a $50 \%$ reduction in the compressive strength of the fibres derived from pyrolytic processing of a sheet moulding compound (SMC) involving a fluidised bed. Nonetheless, the residual glass fibre was used in the manufacture of new composites (polyester dough moulding compound) with no important decline in the mechanical properties of the final product. Some $25 \%$ of the original glass fibre was recycled. Recently, Jie et al. [23] reported a 35\% reduction in the tensile strength of glass fibres recovered from printed circuit boards (made of epoxy resins reinforced with fibreglass) via pyrolysis in a tubular reactor at $450^{\circ} \mathrm{C}$. Torres et al. [24], however, who used a solid residue (glass fibre and $\mathrm{CaCO}_{3}$ ) obtained from the pyrolysis of an SMC material at $500{ }^{\circ} \mathrm{C}$ as a replacement for original fibre and filler in the manufacture of a bulk moulding compound (BMC), found that the physical properties of the latter were not negatively affected by a residue inclusion rate of $6 \%$. Nonetheless, none of these techniques achieves more than the partial recovery of glass fibre and packing.

The present work is the first to propose the reuse of glass fibre in the production of a glassceramic material. Glass-ceramics are polycrystalline materials of fine microstructure that are produced by the controlled crystallisation (devitrification) of a glass. The first glass-ceramics, developed in the 1950s, were produced via a conventional glass-making process, followed by crystallisation involving heating and later cooling (allowing nucleation and crystallisation respectively). In recent years, however, sintering has become a technologically viable route of glass-ceramic manufacture. Sintered glass-ceramics are usually made by milling a glass frit into particles of adequate size, heating to induce sintering, and then allowing crystallisation. 
F.A. López, M.I. Martín, F.J. Alguacil, J.Ma. Rincón, T.A. Centeno, M. Romero. Thermolysis of fibreglass polyester composite and reutilisation of the glass fibre residue to obtain a glass-ceramic material.

Journal of Analytical and Applied Pyrolysis, 93 (2012) 104-112; DOI: 10.1016/j.jaap.2011.10.003

Glass-ceramics have found a wide variety of applications in different technological fields [25]. The most important glass-ceramic for building applications is Neoparies ${ }^{\circledR}$. This wollastonite material is produced on a large scale for building interior and exterior walls. Large flat or curved sheets of this material can also be produced for facing buildings. The main properties of Neoparies ${ }^{\circledR}$ include great resistance to weathering, zero water absorption rate, hardness (which is greater than that of natural stone), light weight (30\% lighter than natural stone building materials), and the ease with which curved panels can be made.

Cryston $^{\circledR}$ is another wollastonite glass-ceramic that can be used as an architectural covering material. The chemical durability of Cryston ${ }^{\circledR}$ is very high, its chemical properties being nearly the same as those of float glass [25].

This paper proposes the valorisation of polyester fibreglass (PFG) waste via thermolysis and the subsequent use of the residual glass fibre as a precursor for the manufacture of a wollastoniteplagioclase glass-ceramic material for architectural applications.

\section{Materials and Methods}

\subsection{Polyester fibreglass waste characterisation}

The PFG waste (Polifibra S.A., Guadalajara, Spain) used in this work was exclusively composed of E-fiberglass $\left(\mathrm{SiO}_{2}: 54.3 \mathrm{wt} \% ; \mathrm{Al}_{2} \mathrm{O}_{3}: 15.2 \mathrm{wt} \%\right.$; $\mathrm{CaO}: 17.2 \mathrm{wt} \%$; $\mathrm{MgO}: 4.7 \mathrm{wt} \%$; $\mathrm{B}_{2} \mathrm{O}_{3}: 8.0 \mathrm{wt} \%$ ) plus unsaturated polyester resin made from orthophtalic acid and styrene. The curing agent for the unsaturated polyester resin was a combination of methyl ethyl ketone peroxide ( $2 \mathrm{wt} \%$ of the resin) and cobalt octoate $(0.2 \mathrm{wt} \%$ of the resin). Table 1 shows the composition (manufactured material) of PFG waste used in the experiments. The total amount of organic matter contained in such PFG waste, deduced from Table 1, is $35.5 \mathrm{wt} \%$; this percentage should correspond to the amount of gases + liquids to be obtained in the thermolisis tests and consequently a solid residue, basically composed of fibre-glass, of $64.5 \mathrm{wt} . \%$ should be obtained. The PGF waste used in this work contained no filler. 
F.A. López, M.I. Martín, F.J. Alguacil, J.Ma. Rincón, T.A. Centeno, M. Romero. Thermolysis of fibreglass polyester composite and reutilisation of the glass fibre residue to obtain a glass-ceramic material.

Journal of Analytical and Applied Pyrolysis, 93 (2012) 104-112; DOI: 10.1016/j.jaap.2011.10.003

The elemental composition of the PFG waste were determined using an automated LECO CHNS 923 analyser (Table 2). A GCV of $9.6 \mathrm{MJ} \mathrm{kg}^{-1}$ was estimated for the PFG waste, derived from the value of the pure resin $\left(26.96 \mathrm{MJ} \mathrm{kg}^{-1}\right)$ [26].

Table 1 Composition of the PFG waste used in the present experiments ( $\mathrm{wt} \%)$.

\begin{tabular}{cccccc}
\hline Component & $\begin{array}{c}\text { Ortho-phthalic } \\
\text { polymer resin }\end{array}$ & $\begin{array}{c}\text { Organic } \\
\text { catalyst }\end{array}$ & $\begin{array}{c}\text { Styrene } \\
\text { monomer }\end{array}$ & $\begin{array}{c}\text { Zn stearate } \\
\text { lubricant }\end{array}$ & Fiber-glass \\
\hline $\begin{array}{c}\text { Proportion } \\
\text { (wt.\%) }\end{array}$ & 32.8 & 0.3 & 1.2 & 1.2 & 64.5 \\
\hline
\end{tabular}

Table 2 Elemental composition (wt\%) and gross calorific value $\left(\mathrm{MJ} \mathrm{kg}^{-1}\right)$ of the PFG waste and recycled glass fibre obtained by thermolysis.

\begin{tabular}{lccccc}
\hline & $\begin{array}{c}\mathrm{C} \\
(\mathrm{wt} \%)\end{array}$ & $\begin{array}{c}\mathrm{H} \\
(\mathrm{wt} \%)\end{array}$ & $\begin{array}{c}\mathrm{O}^{\mathrm{a}} \\
(\mathrm{wt} \%)\end{array}$ & $\begin{array}{c}\mathrm{N} \\
(\mathrm{wt} \%)\end{array}$ & $\begin{array}{c}\mathrm{GCV} \\
\left(\mathrm{MJ} \mathrm{kg}^{-1}\right)\end{array}$ \\
\hline $\begin{array}{l}\text { PGF waste } \\
\begin{array}{c}\text { Glass fiber } \\
\text { residue }\end{array}\end{array}$ & 22.9 & 1.5 & 10.6 & 0 & $9.6^{\mathrm{b}}$ \\
\hline${ }^{\mathrm{a}}$ Calculated by difference & ${ }^{\mathrm{b}}$ Calculated according Shih et al. [31]. & - & - \\
\hline
\end{tabular}

\subsection{Thermolysis experiments}

\subsubsection{Thermal studies of the polyester fibreglass samples}

The thermal behaviour of the PFG samples (granule size 100-200 $\mu \mathrm{m}$ ) was studied using a Setaram Sensys Evolution 1500 thermal analysis system equipped with a differential thermal analyser (DTA) and a thermogravimetric analyser (TGA). The samples (30 mg) were heated at $800^{\circ} \mathrm{C}\left(10^{\circ} \mathrm{C} \mathrm{m^{-1 }}\right)$ in pure air $\left(20 \mathrm{ml} \mathrm{min}^{-1}\right)$.

\subsubsection{Thermolysis of waste polyester fibreglass}

Figure 1 shows the thermolysis installation used in the present work, which consists of a heating system and a gas condensation device. The muffle furnace (1) contains a $9.6 \mathrm{dm}^{3}$ steel reactor, sealed by a screw-on lid. The reactor has an exit orifice for the gases generated during heating, and an orifice via which a thermocouple can be attached to measure the reactor's internal temperature. The flue gases circulate across four condensers (3-6) connected to each other by 
F.A. López, M.I. Martín, F.J. Alguacil, J.Ma. Rincón, T.A. Centeno, M. Romero. Thermolysis of fibreglass polyester composite and reutilisation of the glass fibre residue to obtain a glass-ceramic material.

Journal of Analytical and Applied Pyrolysis, 93 (2012) 104-112; DOI: 10.1016/j.jaap.2011.10.003

six cooling pipes (590 mm length, $15 \mathrm{~mm}$ external diameter). Each condenser is a stainless steel pipe (405 mm length, $60 \mathrm{~mm}$ external diameter) placed at a $15^{\circ}$ slope. This allows for the collection of the distilled oils as the gases cool. Each condenser has four collection holes for the withdrawal of the distilled liquids, and a thermometer to measure their temperature. The noncondensable gases are led to a water-cooling tower (7) where the last fraction of the distilled liquids is collected. These gases pass through a set of three filters ( 8 and 9) (nickel sponge, activated carbon, and a membrane filter) to eliminate pollutant gases and solid particles. The gases can then be mixed with air and burned off or collected in Tedlar plastic bags for analysis. When thermolysis is complete (the endpoint being determined via the rotameter (10) inside the tubing detecting no more distillation gas), the reactors are cooled and the thermolytic solid residues removed.

The amount of gas generated was estimated by the difference between the initial weight of PFG and the amount of liquids and solids obtained.

A typical run involved the thermolysis of about $4 \mathrm{~kg}$ of PFG pieces measuring $12 \times 4 \mathrm{~cm}$. Based on preliminary DTA/TGA studies, $550^{\circ} \mathrm{C}$ was selected as the working temperature. The experiment was performed in triplicate.

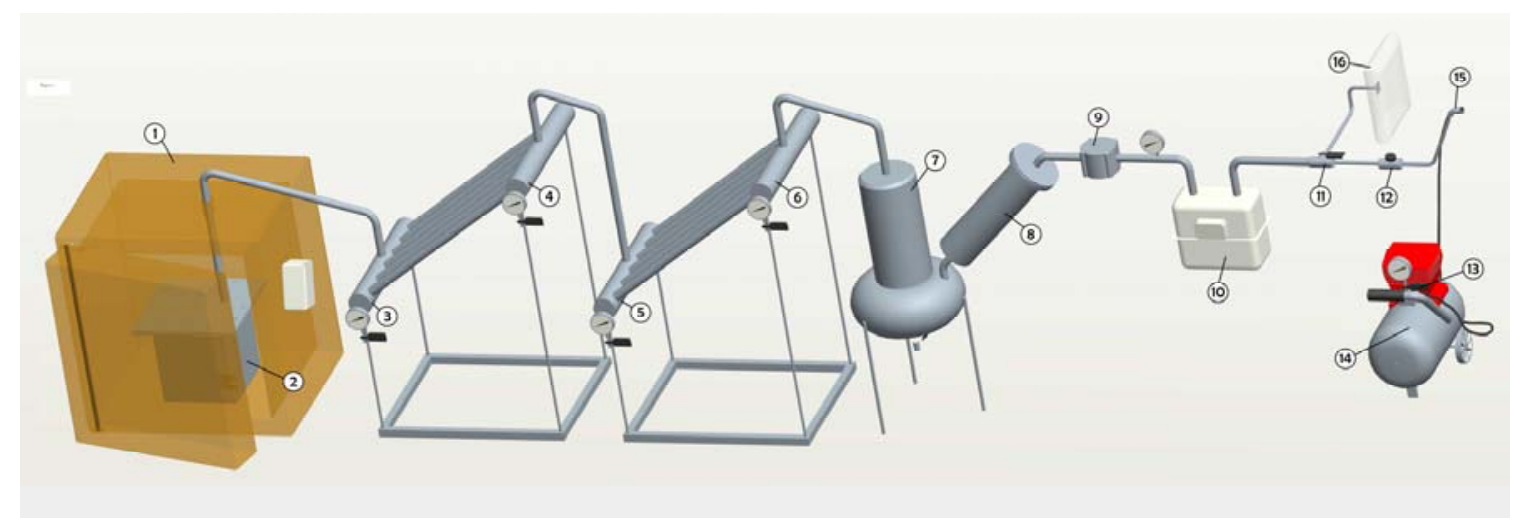

Figure 1 Installation used for the thermolysis of the PFG 
F.A. López, M.I. Martín, F.J. Alguacil, J.Ma. Rincón, T.A. Centeno, M. Romero. Thermolysis of fibreglass polyester composite and reutilisation of the glass fibre residue to obtain a glass-ceramic material.

Journal of Analytical and Applied Pyrolysis, 93 (2012) 104-112; DOI: 10.1016/j.jaap.2011.10.003

\subsection{Characterisation of the products of polyester fibreglass thermolysis}

\subsubsection{Liquid fraction (oil)}

The elemental composition and GCV of the thermolysis liquid (oil) were determined using an automated LECO CHNS 923 analyser and an IKAWEEME C4000 automatic bomb calorimeter respectively. The oil product was dissolved in dichloromethane (DCM) and analyzed mainly by gas chromatography/mass spectrometry (GC/MS) using a GCMS-QP2010-Plus chromatograph (Shimadzu, Scientific Instruments) with and Teknokroma TRB-WAX (100\% Polietilenglicol (PEG)) capillary column: $20 \mathrm{~m}$ in length, $0.1 \mathrm{~mm}$ diameter and $0.1 \mu \mathrm{m}$ film thickness. The carrier gas was helium. The GC/MS oven temperature programme used for the separation of oil components was a follows: the oven was held at $40{ }^{\circ} \mathrm{C}$ for $1 \mathrm{~min}$, then ramped at $4{ }^{\circ} \mathrm{C} / \mathrm{min}$ to $230{ }^{\circ} \mathrm{C}$ where it was held for a further $25 \mathrm{~min}$. The MS detector was operated at full scan from was 45 to $350 \mathrm{amu}$. The ion-mass spectra derived were automatically compared to the NIST 08 spectra library and similarity of $>95 \%$ were used to identify compounds. Samples were injected using an AOC-20i autoinjector (Shimadzu).

The flashpoint of the oil was estimated using a STANHOPE-SETA Setaflash 3 apparatus and a closed cup system (ASTM D1655). The kinematic viscosity was determined at $40^{\circ} \mathrm{C}$ using a THERMO SCIENTIFIC Haake 1 plus viscosimeter. The water content was analysed by KarlFischer titration (titrant: Hydranal Composite 5K. [Fluka]) using a Karl-Fischer MKS-520 Moisture Titrator.

To obtain the distillation curves, pooled sample of the oils obtained in different runs at $550^{\circ} \mathrm{C}$ were subjected to automatic distillation tests using a PAC OptiDist apparatus following the ASTM D86 method at atmospheric pressure. Testing was performed from room temperature up to the temperature at which no more distillation products were collected.

\subsubsection{Gases}

The thermolytic gas produced was analysed by gas chromatography using a HEWLETTPACKARD 5890 chromatograph equipped with a Porapak N and Molecular Sieve multicolumn system, a thermal conductivity detector (TCD), and a flame ionisation detector (FID). The carrier gas $(0.39 \mathrm{MPa})$ was $\mathrm{He}(99.999 \%$ pure). The GCV of the dry gas was calculated according to the equation proposed by Xiao et al. [27]. 
F.A. López, M.I. Martín, F.J. Alguacil, J.Ma. Rincón, T.A. Centeno, M. Romero. Thermolysis of fibreglass polyester composite and reutilisation of the glass fibre residue to obtain a glass-ceramic material.

Journal of Analytical and Applied Pyrolysis, 93 (2012) 104-112; DOI: 10.1016/j.jaap.2011.10.003

\subsubsection{Solid fraction}

Proximal and elemental analyses of the solid residue particles were undertaken using a LECO TGA 701 and LECO CHNS 923 analyser respectively. Morphological studies of the solid residue were performed using a Hitachi model S-2100 scanning electron microscope (SEM).

\subsection{Glass-ceramic production}

The solid residue left after thermolysis was ground using a RETSCH PM 100 ball mill at 500 rpm for 15 min. $47.5 \mathrm{~g}$ of the resulting powder (particle size $<250 \mu \mathrm{m}$ ) was then mixed with 4.3 $\mathrm{g}$ of $\mathrm{Na}_{2} \mathrm{O}$ (from $\mathrm{Na}_{2} \mathrm{CO}_{3}$ ) in a Turbula blender for $30 \mathrm{~min}$, placed in an aluminosilicate crucible and melted in an electric furnace at $1450^{\circ} \mathrm{C}\left(10^{\circ} \mathrm{C} / \mathrm{min}\right)$ for $120 \mathrm{~min}$. The molten material was then poured into water, to produce a glass frit.

This frit was then ground using a RETSCH PM 100 ball mill at $400 \mathrm{rpm}$, and 11 fractions of different sized particles separated (see Table 3) with the aim of determining the effect of particle size on glass crystallisation. The thermal stability of these different glass fractions and their preferential crystallisation mechanisms (surface or bulk) were studied by DTA employing a SETARAM LABSYS TG apparatus. DTA analyses were performed between $25^{\circ} \mathrm{C}$ and $1400^{\circ} \mathrm{C}$ in air, using calcined $\mathrm{Al}_{2} \mathrm{O}_{3}$ as a reference material. All analyses were performed at a heating rate of $50^{\circ} \mathrm{C} / \mathrm{min}$. The DTA curves were normalised to sample weight. Mineralogical study of crystalline phases devitrified by thermal treatment was performed by X-ray diffraction (XRD) using a PHILIPS X 'PERT MPD (operating at $50 \mathrm{kV}$ and $30 \mathrm{~mA}$ ) employing $\mathrm{Cu} \mathrm{K}_{\alpha}$ radiation.

The feasibility of the sintering + crystallization process to produce glass-ceramic tiles was evaluated on a mixture of different particle size glass powders: 1600-2000 $\mu \mathrm{m}, 160-250 \mu \mathrm{m}$ and $80-100 \mu \mathrm{m}$. We chose to work with a mixture of different particle sizes because it leads to materials similar to natural stone. The percentages of the different fractions (1600-2000 $\mu \mathrm{m}$ (47 $\mathrm{wt} \%), 160-250 \mu \mathrm{m}(32 \mathrm{wt} \%)$ and $80-100 \mu \mathrm{m}(21 \mathrm{wt} \%))$ were randomly chosen. Forming by pressure with the aid of a binder is feasible when using very fine powder. In this case the majority fraction $(47 \mathrm{wt} \%)$ is coarse $(1600-2000 \mu \mathrm{m})$, so the most appropriate method is compaction by vibration. The mixture was compacted in a plaster mould and afterward fired at $1013^{\circ} \mathrm{C}$ for 60 minutes with heating and cooling rate of $50^{\circ} \mathrm{C} / \mathrm{min}$. 
F.A. López, M.I. Martín, F.J. Alguacil, J.Ma. Rincón, T.A. Centeno, M. Romero. Thermolysis of fibreglass polyester composite and reutilisation of the glass fibre residue to obtain a glass-ceramic material.

Journal of Analytical and Applied Pyrolysis, 93 (2012) 104-112; DOI: 10.1016/j.jaap.2011.10.003

Table 3 Glass frit particle size fractions separated by mechanical milling and sieving.

\begin{tabular}{cc}
\hline Fraction & $\begin{array}{c}\text { Particle size range } \\
(\mu \mathrm{m})\end{array}$ \\
\hline $\mathrm{f} 1$ & $2000-5000$ \\
$\mathrm{f} 2$ & $1600-2000$ \\
$\mathrm{f} 3$ & $1000-1600$ \\
$\mathrm{f} 4$ & $500-1000$ \\
$\mathrm{f} 5$ & $400-500$ \\
$\mathrm{f} 6$ & $250-400$ \\
$\mathrm{f} 7$ & $160-250$ \\
$\mathrm{f} 8$ & $100-160$ \\
$\mathrm{f} 9$ & $80-100$ \\
$\mathrm{f} 10$ & $63-80$ \\
$\mathrm{f} 11$ & $<63$ \\
\hline
\end{tabular}

\section{Results and Discussion}

\subsection{Thermal studies of the polyester fibreglass samples}

Figure 2 shows the TG/DTG curves for the thermal degradation of PFG waste in air. Table 4 shows the peak temperatures and mass losses for the different degradation phases. The first phase (dehydration) temperature peak occurs at around $210^{\circ} \mathrm{C}$. The second and main phase of degradation temperature peak occurs between $259^{\circ} \mathrm{C}$ and $392^{\circ} \mathrm{C}$. In the isophthalic acid-based polyester resin the second step involves scission at the cross-link and formation of styrene and the linear polyester which subsequently breaks randomly [28-32]. The third phase (formation of primary carbonaceous material or char) peak occurs at around $449^{\circ} \mathrm{C}$. The formation of char is due to secondary repolymerization reactions among the polymer derived products. The total mass loss over the temperature interval $20-800^{\circ} \mathrm{C}$ was $32.6 \mathrm{wt} \%$.

\subsection{Thermolysis of the polyester fibreglass samples}

\subsubsection{Thermolytic yields}

The yield of solid residue was $68.1 \pm 0.8 \mathrm{wt} \%$; the oil and gas fractions accounted for $23.9 \pm 0.1$ $\mathrm{wt} \%$ and $8.0 \pm 0.9 \mathrm{wt} \%$ respectively. The liquid + gas yield $(31.9 \pm 0.8 \mathrm{wt} \%)$ was somewhat lower than the theoretical value that should be expected from table 1. The difference may be attributed to char formation. 
F.A. López, M.I. Martín, F.J. Alguacil, J.Ma. Rincón, T.A. Centeno, M. Romero. Thermolysis of fibreglass polyester composite and reutilisation of the glass fibre residue to obtain a glass-ceramic material.

Journal of Analytical and Applied Pyrolysis, 93 (2012) 104-112; DOI: 10.1016/j.jaap.2011.10.003

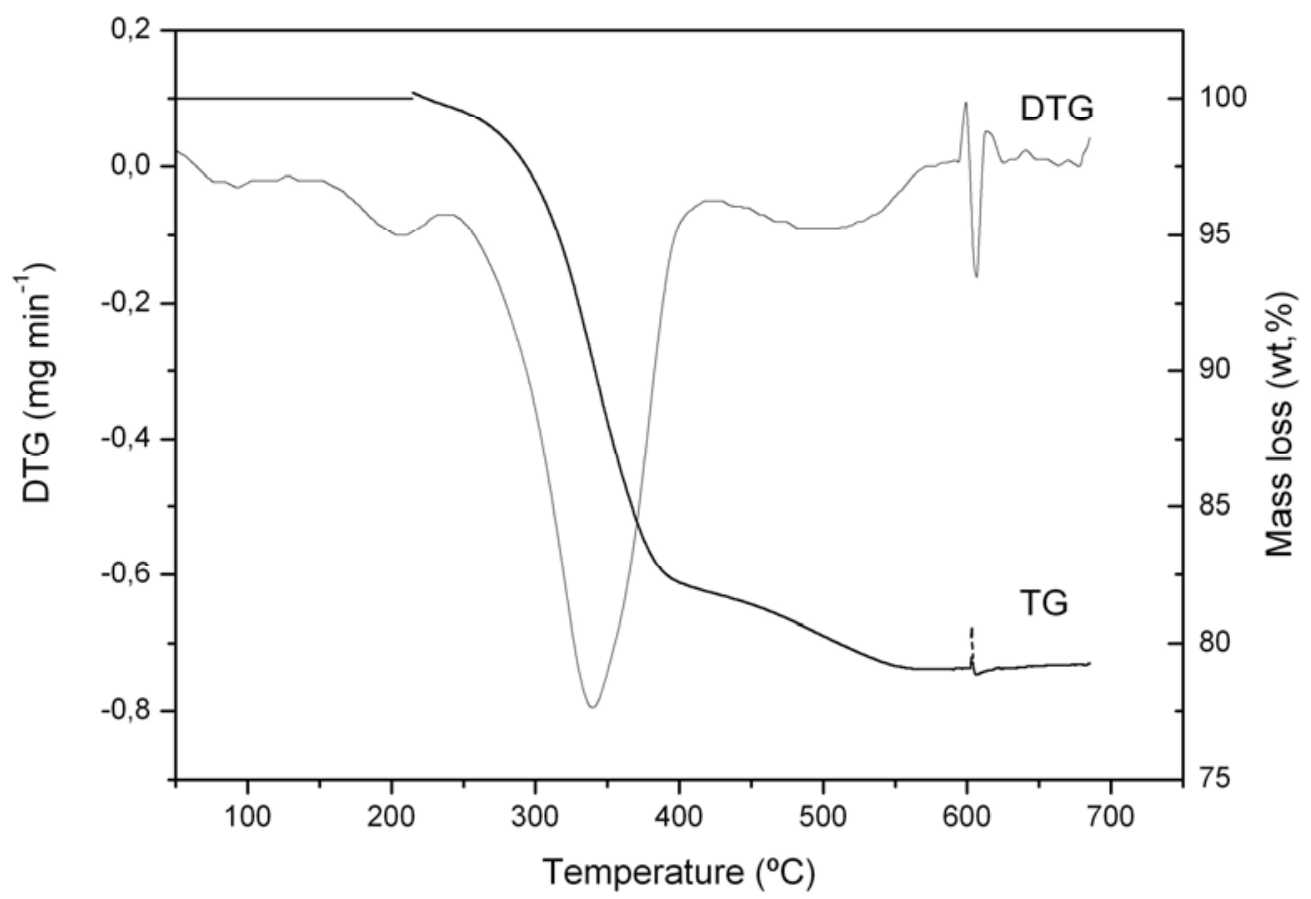

Figure 2 TG/DTG curves for PFG waste when thermally degraded in air.

Table 4 Characteristic temperatures of the three degradation phases of PFG waste in air.

\begin{tabular}{|c|c|c|c|c|c|}
\hline \multicolumn{2}{|c|}{ Step 1} & \multicolumn{2}{|c|}{ Step 2} & \multicolumn{2}{|c|}{ Step 3} \\
\hline $\begin{array}{c}\text { Peak } \\
\text { Temperature } \\
\left({ }^{\circ} \mathrm{C}\right)\end{array}$ & $\begin{array}{l}\text { Mass loss } \\
(\mathrm{wt} \%)\end{array}$ & $\begin{array}{c}\text { Peak } \\
\text { Temperature } \\
\left({ }^{\circ} \mathrm{C}\right)\end{array}$ & $\begin{array}{l}\text { Mass loss } \\
(\mathrm{wt} \%)\end{array}$ & $\begin{array}{c}\text { Peak } \\
\text { Temperature } \\
\left({ }^{\circ} \mathrm{C}\right)\end{array}$ & $\begin{array}{c}\text { Mass loss } \\
\quad(w t \%)\end{array}$ \\
\hline 209.8 & 1.8 & 334.6 & 26.4 & 448.7 & 4.4 \\
\hline
\end{tabular}

\subsubsection{Characteristics of the solid residue}

The solid residue obtained by thermolysis was composed of pieces of dimensions equal to those of the input material, but completely black (Figure 3).

Figure 4 shows the microstructure of the initial PFG waste (a) and the glass fibre after thermolysis at $550^{\circ} \mathrm{C}$ (b). Char can be seen on the surface of the fibres. It has been reported $[3,16,23]$ that a certain amount of char or coke-like material is formed during the pyrolysis of many polymeric materials due to secondary repolymerisation reactions in the gaseous phase. 
F.A. López, M.I. Martín, F.J. Alguacil, J.Ma. Rincón, T.A. Centeno, M. Romero. Thermolysis of fibreglass polyester composite and reutilisation of the glass fibre residue to obtain a glass-ceramic material.

Journal of Analytical and Applied Pyrolysis, 93 (2012) 104-112; DOI: 10.1016/j.jaap.2011.10.003

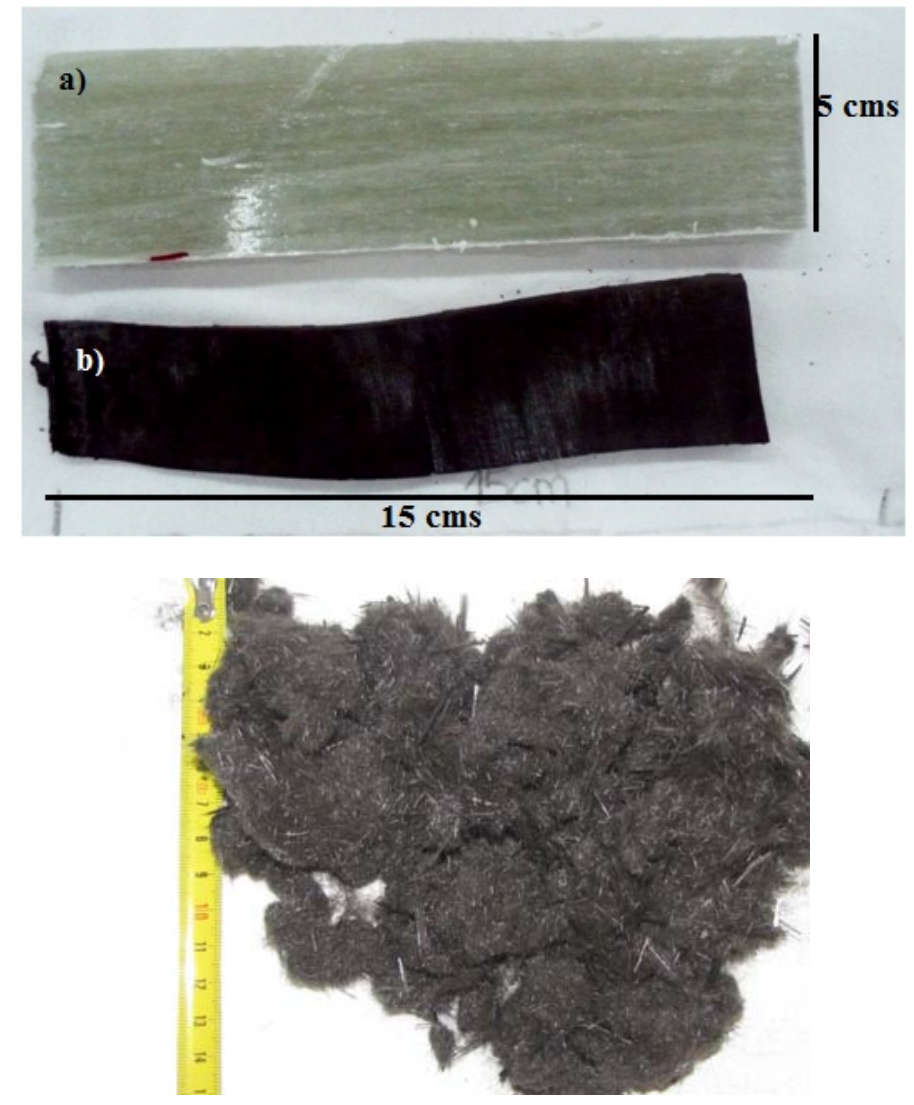

Figure 3 (a) PFG fragment, (b) glass fibre obtained after thermolysis, (c) glass fibre obtained after grinding.

The amount of char formed in the thermolysis process was analysed by TGA of the solid residue at $700^{\circ} \mathrm{C}$ in $\mathrm{O}_{2}$, and recorded as about $2.9 \mathrm{wt} \%$.

The inorganic matter in the solid thermolysis residue calculated according to the equation proposed by Torres et al. [24] corresponded to $65 \mathrm{wt} \%$, in agreement with the composition of the PFG waste (Table 1). This confirms that the polyester resin was fully decomposed at the $550^{\circ} \mathrm{C}$ thermolytic temperature used.

The thermolysis solid residue was essentially composed of $97 \mathrm{wt} \%$ glass fibre and $3 \mathrm{wt} \%$ char (from secondary repolymerisation reactions). The char does not interfere in the process of obtention of glass-ceramic materials. The vitrification process removes this char and burnt it and therefore it does not interfere in the process. 
F.A. López, M.I. Martín, F.J. Alguacil, J.Ma. Rincón, T.A. Centeno, M. Romero. Thermolysis of fibreglass polyester composite and reutilisation of the glass fibre residue to obtain a glass-ceramic material.

Journal of Analytical and Applied Pyrolysis, 93 (2012) 104-112; DOI: 10.1016/j.jaap.2011.10.003
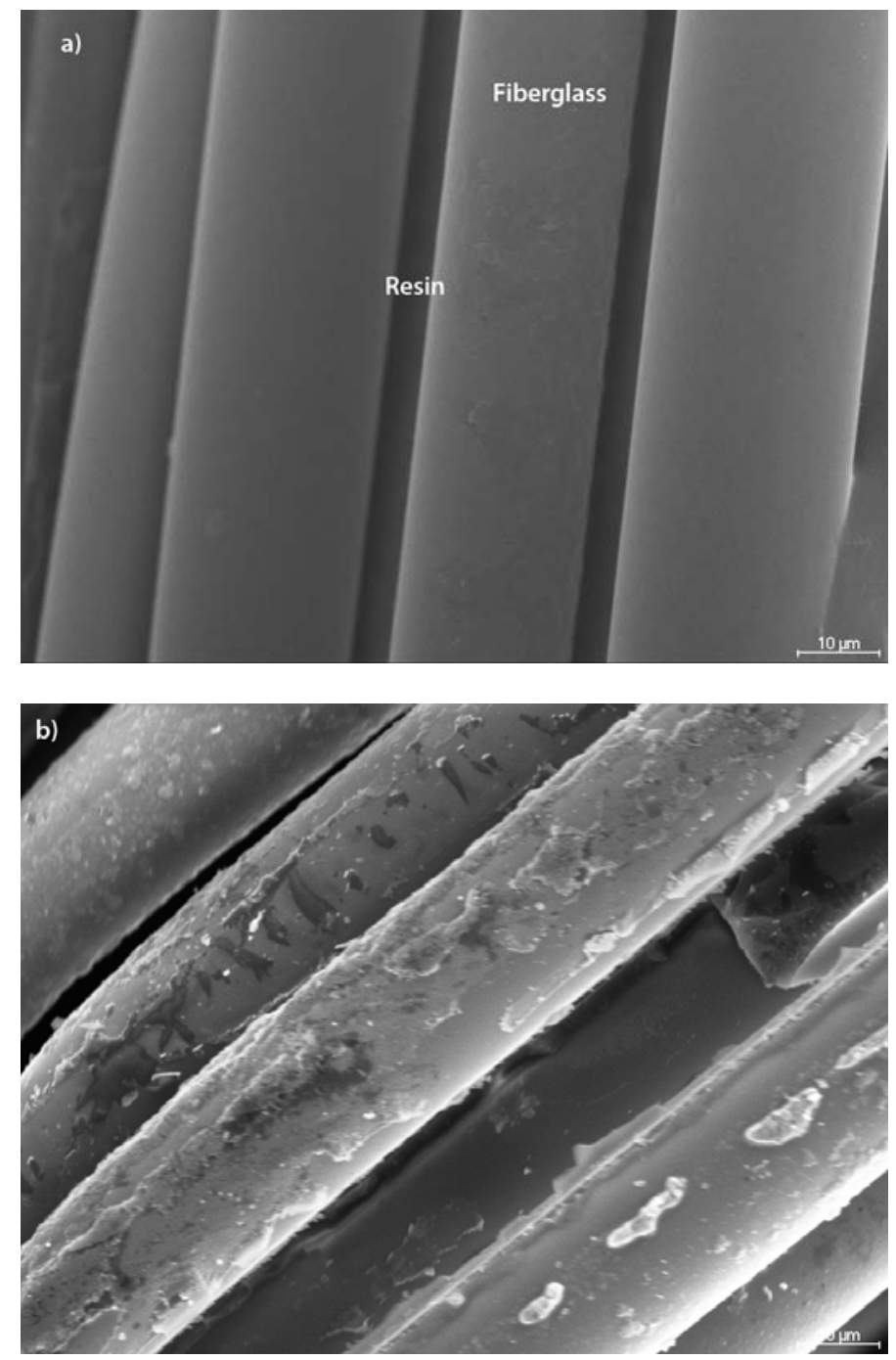

Figure 4 SEM images showing glass fibres (a) in the PFG waste and (b) after thermolysis.

Table 2 shows the carbon content in the glass fibre residue to reach $2.4 \mathrm{wt} \%$. This content is very similar to the 2.5-3.6 wt\% indicated by Torres et al. [24] after the pyrolysis of SMC at $500^{\circ} \mathrm{C}$. However, it is much lower than that obtained by Pickering (16 wt \%) [3].

\subsubsection{Oil characterisation}

The $\mathrm{H} / \mathrm{C}$ atomic ratio of the distilled oil was rather low $(\approx 1.2)$, indicating it to be mainly aromatic in nature. Its $\mathrm{GCV}, 33.9 \mathrm{MJ} \mathrm{kg}^{-1}$, is similar to that of a fuel oil (Table 5). 
F.A. López, M.I. Martín, F.J. Alguacil, J.Ma. Rincón, T.A. Centeno, M. Romero. Thermolysis of fibreglass polyester composite and reutilisation of the glass fibre residue to obtain a glass-ceramic material.

Journal of Analytical and Applied Pyrolysis, 93 (2012) 104-112; DOI: 10.1016/j.jaap.2011.10.003

Table 5 Elemental composition (wt\%), $\mathrm{H} / \mathrm{C}$ atomic ratio and gross calorific value $\left(\mathrm{MJ} \mathrm{kg}^{-1}\right)$ of the oil obtained at $550^{\circ} \mathrm{C}$.

\begin{tabular}{ccccccccc}
\hline $\begin{array}{c}\mathrm{C} \\
(\mathrm{wt} \%)\end{array}$ & $\begin{array}{c}\mathrm{H} \\
(\mathrm{wt} \%)\end{array}$ & $\begin{array}{c}\mathrm{O} \\
(\mathrm{wt} \%)\end{array}$ & $\begin{array}{c}\mathrm{N} \\
(\mathrm{wt} \%)\end{array}$ & $\begin{array}{c}\mathrm{H} / \mathrm{C} \\
\text { ratio }\end{array}$ & $\begin{array}{c}\mathrm{GCV} \\
\left(\mathrm{MJ} \mathrm{kg}^{-1}\right)\end{array}$ & $\begin{array}{c}\text { Density at } \\
20^{\circ} \mathrm{C} \\
\left(\mathrm{kg} \mathrm{m}^{-3}\right)\end{array}$ & $\begin{array}{c}\text { Viscosity } \\
\text { at } 40{ }^{\circ} \mathrm{C} \\
(\mathrm{cSt})\end{array}$ & $\begin{array}{c}\text { Flash } \\
\text { point } \\
\left({ }^{\circ} \mathrm{C}\right)\end{array}$ \\
\hline 75.2 & 7.5 & 16.1 & 0.1 & 1.2 & 33.9 & 0.94 & 1.77 & $<20$ \\
\hline
\end{tabular}

The oil is in fact a mixture of organic compounds and aqueous products. The water content was $2.4 \mathrm{wt} \%$, whereas the water content of the original PFG was $0.5 \mathrm{wt} \%$. Taking into account mass loss by dehydration determined from the TGA curve (1.8 wt $\%$ ), the $2.4 \mathrm{wt} \%$ water content of the oil results from the inherent PFG moisture and the water generated by the breakage of oxygenated organic compounds during thermolysis. Similar results have previously been reported [12,34-36].

The compounds tentatively identified in the GC/MS chromatogram, and the subsequent comparison of the relative areas under each peak, clearly show the predominantly aromatic nature of the oil. Table 6 summarises the major fractions of volatile organic compounds. The oil is thus a complex mixture of $\mathrm{C}_{5}-\mathrm{C}_{21}$ organic compounds, basically of aromatic structure $(\approx 84 \%)$, plus a relatively high content of oxygenated species $(\approx 16 \%)$.

As shown in Table 6, the major PFG degradation product was styrene. Toluene, ethylbenzene, $\alpha$-methyl styrene and 3-butynyl benzene were also detected. The polyester portion of PFG waste degraded mostly into benzoic acid and 1,2-benzenedicarboxylic acid anhydride (o-phthalic acid anhydride). The formation of the 1,2-benzenedicarboxylic acid anhydride involves alkyl-oxygen scission of the polyester chain. The carboxylate group $\left(\mathrm{COO}^{-}\right)$generated can react with the adjacent ester group to form the acid anhydride [37]. The formation of the benzoic acid - from polystyrene resin containing $\beta$ hydrogen atoms - involves alkyl-oxygen scission via a sixmembered transition state to produce a carboxylic acid and a vinyl ester. The structure of the vinyl ester produced from the polyester resin is dependent upon the type of alcohol used to prepare the polyester. The presence of benzoic acid in the oil indicates that propanediol was used in the preparation of the polyester. 
F.A. López, M.I. Martín, F.J. Alguacil, J.Ma. Rincón, T.A. Centeno, M. Romero. Thermolysis of fibreglass polyester composite and reutilisation of the glass fibre residue to obtain a glass-ceramic material.

Journal of Analytical and Applied Pyrolysis, 93 (2012) 104-112; DOI: 10.1016/j.jaap.2011.10.003

Table 6 Tentative characterisation of the oil obtained by PFG thermolisis at $550^{\circ} \mathrm{C}$ (quantitative estimation based on the relative area under each peak).

\begin{tabular}{|c|c|c|c|}
\hline Peak n ${ }^{\circ}$ & $\begin{array}{l}\text { Retention } \\
\text { time (min) }\end{array}$ & $\begin{array}{c}\text { Peak area } \\
(\%)\end{array}$ & Compounds \\
\hline 1 & 5.968 & 0.94 & Benzene \\
\hline 2 & 6.271 & 0.26 & 1,3-Dioxolane, 2-methyl \\
\hline 3 & 6.407 & 0.17 & 2-(2-Methoxyethoxy)ethyl acetate \\
\hline 4 & 6.916 & 0.01 & di-tert-Butyl dicarbonate \\
\hline 6 & 8.04 & 1.60 & 1,3-Dioxolane, 2-ethyl-4-methyl \\
\hline 7 & 8.398 & 9.50 & Toluene \\
\hline 8 & 8.556 & 2.40 & Hexane, 3-methoxy \\
\hline 9 & 9.001 & 0.02 & Cyclopropane, propyl \\
\hline 10 & 9.157 & 0.08 & 1,4-Dioxane \\
\hline 11 & 9.711 & 0.00 & Methylglyoxal \\
\hline 12 & 10.713 & 0.79 & 2-Propen-1-ol \\
\hline 13 & 10.928 & 15.00 & Ethylbenzene \\
\hline 14 & 11.318 & 0.01 & Ethylbenzene \\
\hline 15 & 12.025 & 0.10 & Furan, 2,5-dihydro-3,4-dimethyl \\
\hline 16 & 12.351 & 3.24 & Benzene, (1-methylethyl) \\
\hline 17 & 12.566 & 0.11 & Propanoic acid, 2-allyloxy-, ethyl ester \\
\hline 18 & 12.717 & 0.01 & Oxalic acid, butyl propyl ester \\
\hline 19 & 13.121 & 0.02 & Propanoic acid, 2-hydroxy-2-methyl \\
\hline 20 & 13.411 & 0.54 & Benzene, propyl \\
\hline 21 & 14.429 & 0.29 & 1-Propene, 3,3',3"-[methylidynetris(oxy)]tris \\
\hline 22 & 14.908 & 25.77 & Styrene \\
\hline 23 & 15.116 & 0.31 & Benzene, 1-ethenyl-4-methyl \\
\hline 24 & 16.537 & 0.40 & Benzene, butyl \\
\hline 25 & 17.084 & 7.63 & alpha.-Methylstyrene \\
\hline 26 & 17.292 & 0.02 & Ethanone, 2-(5-nitrotetrazol-2-yl)-1-phenyl- \\
\hline 27 & 17.917 & 0.85 & 2-Benzyloxyphenylacetonitrile \\
\hline 28 & 18.843 & 0.27 & 1,3,5-Cycloheptatriene, 7,7-dimethyl \\
\hline 29 & 19.208 & 0.50 & o-Methylstyrene \\
\hline 30 & 22.703 & 0.40 & Benzaldehyde \\
\hline 31 & 25.778 & 0.23 & Ethanone, 2,2-dihydroxy-1-phenyl \\
\hline 32 & 26.056 & 0.26 & Acetophenone \\
\hline 33 & 26.333 & 0.17 & Benzoylformic acid \\
\hline 34 & 29.379 & 0.11 & Benzoic acid, 2-(benzoylthio)thiazol-4-yl ester \\
\hline 35 & 29.933 & 0.54 & Ethanedione, diphenyl \\
\hline 36 & 30.151 & 0.08 & Benzamide, 4-benzoyl-N-(immino)(methylthio) \\
\hline 37 & 31.678 & 0.22 & Naphthalene, 1-methyl \\
\hline 38 & 33.837 & 0.30 & Acenaphthene \\
\hline 39 & 36.054 & 0.16 & Naphthalene, 1-(2-propenyl) \\
\hline 40 & 36.229 & 0.42 & Benzyl sulfone \\
\hline 41 & 39.001 & 0.71 & Benzene, 1,1'-(1-methyl-1,3-propanediyl)bis \\
\hline 43 & 40.219 & 3.00 & Dimethyl phthalate or pthalic acid \\
\hline 44 & 41.314 & 1.51 & Benzene, 3-butynyl \\
\hline 45 & 43.024 & 4.30 & Benzoic acid \\
\hline 46 & 43.415 & 2.52 & 1,2-Diphenylcyclopropane \\
\hline
\end{tabular}


F.A. López, M.I. Martín, F.J. Alguacil, J.Ma. Rincón, T.A. Centeno, M. Romero. Thermolysis of fibreglass polyester composite and reutilisation of the glass fibre residue to obtain a glass-ceramic material.

Journal of Analytical and Applied Pyrolysis, 93 (2012) 104-112; DOI: 10.1016/j.jaap.2011.10.003

The oil contained about $27 \%$ styrene. Thus, this oil has potential as a feedstock for the manufacture of polyester resin.

Figure 5 shows the results obtained for the oil in the automatic distillation test. The initial boiling point of the oil was $69.8^{\circ} \mathrm{C}$ and the final boiling point $340.7^{\circ} \mathrm{C}$. Some $50 \%$ of the volume of the oil has a boiling point between $70^{\circ}$ and $251^{\circ} \mathrm{C}$, which falls into the range of commercial gasoline. The remaining $50 \mathrm{wt} \%$, contained compounds with a boiling point between $251^{\circ} \mathrm{C}$ and $340.7^{\circ} \mathrm{C}$, and could be used as heating fuel when mixed with commercial fuel oils. The distillation residue represented $2 \mathrm{vol} \%$ of the initial sample.

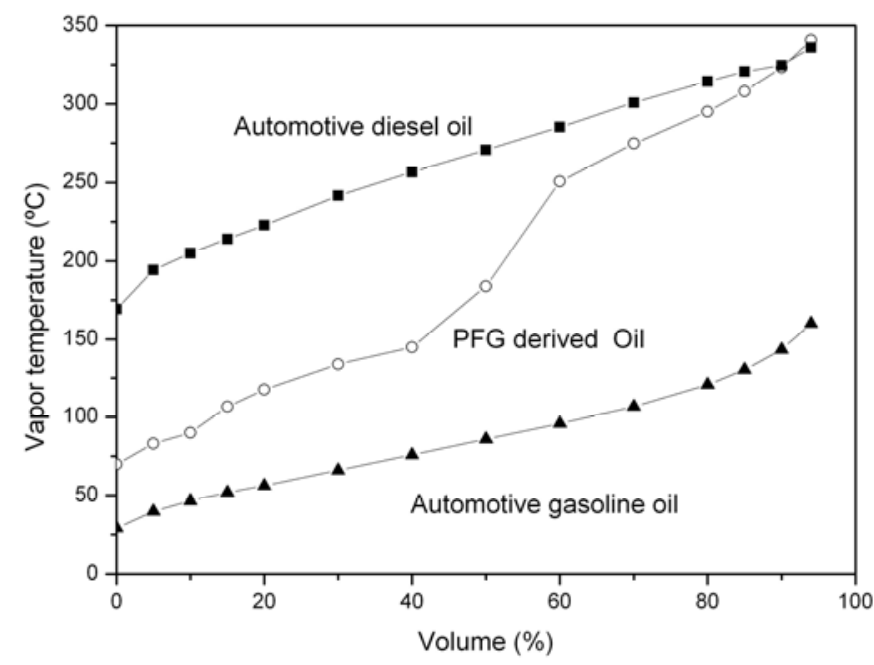

Figure 5 Distillation data for poliested fiber glass derived-oil, automotive diesel and gasoline oils.

\subsubsection{Gas characterisation}

The gas produced in PFG thermolysis (Table 7) was mostly a mixture of $\mathrm{CO}_{2}$ and $\mathrm{CO}$; the hydrocarbon fraction was below $10 \mathrm{vol} \%$. This gas had a gross calorific value (GCV) of about $26 \mathrm{MJ} \mathrm{Nm}^{-3}$; similar results have been reported by other authors $[11,12,38]$. This value is rather low for it to be used to as a fuel for gas turbines; a value of $>40 \mathrm{MJ} \mathrm{Nm}^{-3}$ and greater contents of $\mathrm{H}_{2}$ and $\mathrm{CH}_{4}$ are usually required. However, this gas is suitable for heating the thermolysis reactor. 
F.A. López, M.I. Martín, F.J. Alguacil, J.Ma. Rincón, T.A. Centeno, M. Romero. Thermolysis of fibreglass polyester composite and reutilisation of the glass fibre residue to obtain a glass-ceramic material.

Journal of Analytical and Applied Pyrolysis, 93 (2012) 104-112; DOI: 10.1016/j.jaap.2011.10.003

Other composite residues containing a greater resin content or resins other than polyester (e.g., vinylester, phenolic, urea formaldehyde or epoxy resin), would yield gases with higher GCVs and greater $\mathrm{H}_{2}$ contents. These could certainly be revalorised as gas turbine fuels. Jie et al. [23] produced gases with $38.5 \% \mathrm{H}_{2}$ and $15 \% \mathrm{C}_{1}-\mathrm{C}_{4}$ hydrocarbons from the pyrolysis of printed circuit boards containing epoxy resins.

Table 7 Composition (vol\%) and gross calorific value $\left(\mathrm{MJ} \mathrm{Nm}^{-3}\right.$ ) of the thermolyticallyproduced gases.

\begin{tabular}{lc}
\hline \multicolumn{1}{c}{ Gas } & Vol.\% \\
\hline $\mathrm{H}_{2}$ & 2.30 \\
$\mathrm{O}_{2}$ & 1.51 \\
$\mathrm{~N}_{2}$ & 6.76 \\
$\mathrm{CO}$ & 21.46 \\
$\mathrm{CO}_{2}$ & 37.51 \\
$\mathrm{CH}_{4}$ & 8.97 \\
$\mathrm{C}_{2} \mathrm{H}_{4}$ (ethene) & 3.69 \\
$\mathrm{C}_{2} \mathrm{H}_{6}$ (ethane) & 7.98 \\
$\mathrm{C}_{3} \mathrm{H}_{6}$ (propene) & 6.50 \\
$\mathrm{C}_{3} \mathrm{H}_{8}$ (propane) & 0.69 \\
$\mathrm{nC}_{4} \mathrm{H}_{10}$ (n-butane) & 1.71 \\
isoC $_{4} \mathrm{H}_{10}$ (isobutane) & 0.27 \\
$\mathrm{H}_{2} \mathrm{~S}$ & n.d. \\
$\mathrm{NH}_{3}$ & n.d. \\
$\mathrm{GCV}$ (MJ Nm & \\
\hline
\end{tabular}

\subsection{Glass characterization}

Figure 6 depicts the DTA curves of both powdered $(<63 \mu \mathrm{m})$ and bulk glass produced from the post-thermolysis solid residue, and for the different size fractions. As expected, both curves (Fig 6a) show a glass transition, $\mathrm{Tg}$, at $672^{\circ} \mathrm{C}$, because this temperature is independent of glass particle size and it is just related to glass composition and to the cooling rate from melting temperature. DTA thermogram of powder glass sample shows two distinct crystallization 
F.A. López, M.I. Martín, F.J. Alguacil, J.Ma. Rincón, T.A. Centeno, M. Romero. Thermolysis of fibreglass polyester composite and reutilisation of the glass fibre residue to obtain a glass-ceramic material.

Journal of Analytical and Applied Pyrolysis, 93 (2012) 104-112; DOI: 10.1016/j.jaap.2011.10.003

exothermic peaks at $818^{\circ}$ and $1013^{\circ} \mathrm{C}$ respectively, followed by two endothermic reactions indicating formation of liquid phases. In contrary, DTA curve recorded on bulk glass sample shows no exothermic peaks, indicating that bulk glass is thermally stable and crystallization by heating does not occur. This behavior indicates that after subsequent thermal treatments, the glass will devitrify through a surface crystallization mechanism and therefore, the most appropriate method for glass-ceramic materials production will be through a sintering + crystallization.

To assess the effect of particle size on crystallization, Figure $6 \mathrm{~b}$ and $6 \mathrm{c}$ shows the DTA curves recorded on the different particle size fractions (Table 3). It is noted that increasing particle size leads to a decrease in the height of crystallization peaks (Figure 6c), which even disappear from the curve recorded on 1000-1600 $\mu \mathrm{m}$ fraction (Figure $6 \mathrm{~b}$ ). The exothermic peak centered at $818^{\circ} \mathrm{C}$ is undetectable in fractions with particle size larger than $100 \mu \mathrm{m}$, whereas crystallization peak at $1013^{\circ} \mathrm{C}$ is not perceptible for particles above $1000 \mu \mathrm{m}$. Consequently, DTA curves recorded on particles larger than $1000 \mu \mathrm{m}$ do not show any exothermic peak, indicating that these fractions are very stable against crystallization. These results verify that surface crystallization plays a major role in crystallization of the present glass. Similar findings have been reported for other materials [39-42].

Figure 7 shows the X-ray diffractogram of powder glass sample after thermal treatment at $1013^{\circ} \mathrm{C}$ for $60 \mathrm{~min}$. Glass devitrification leads to a glass-ceramic material composed of wollastonite $\left(\mathrm{CaSiO}_{3}\right)$ and plagioclase s.s., which corresponds to a series of solid solution between albite $\left(\mathrm{NaAlSi}_{3} \mathrm{O}_{8}\right)$ and anorthite $\left(\mathrm{CaAl}_{2} \mathrm{Si}_{2} \mathrm{O}_{8}\right)$ end-members.

Figure 8 illustrates the appearance of both the glass frit derived from the thermolytic solid residue (Figure 8a) and the glass-ceramic tile obtained by sintering + crystallization of a mixture of different particle size glass powders at $1013^{\circ} \mathrm{C}$ for $60 \mathrm{~min}$ (Figure $8 \mathrm{~b}$ ). It is noted that the glass particles reach an appropriate degree of sintering during heating, resulting in a compact tile. Glass grains with particle size lower than $250 \mu \mathrm{m}$ crystallize during firing and give rise to an opaque ceramic material, whose crystalline phases scatter visible light. By contrast, larger glass particles $(>1600 \mu \mathrm{m})$ are thermally stable and therefore, maintain a high degree of transparency. The combination of matt crystalline region and transparent amorphous grains results in a glass-ceramic material with an aesthetic similar to natural stone. It appears that it could be suitable as ceramic tile for wall covering or floor pavement. 
F.A. López, M.I. Martín, F.J. Alguacil, J.Ma. Rincón, T.A. Centeno, M. Romero. Thermolysis of fibreglass polyester composite and reutilisation of the glass fibre residue to obtain a glass-ceramic material.

Journal of Analytical and Applied Pyrolysis, 93 (2012) 104-112; DOI: 10.1016/j.jaap.2011.10.003
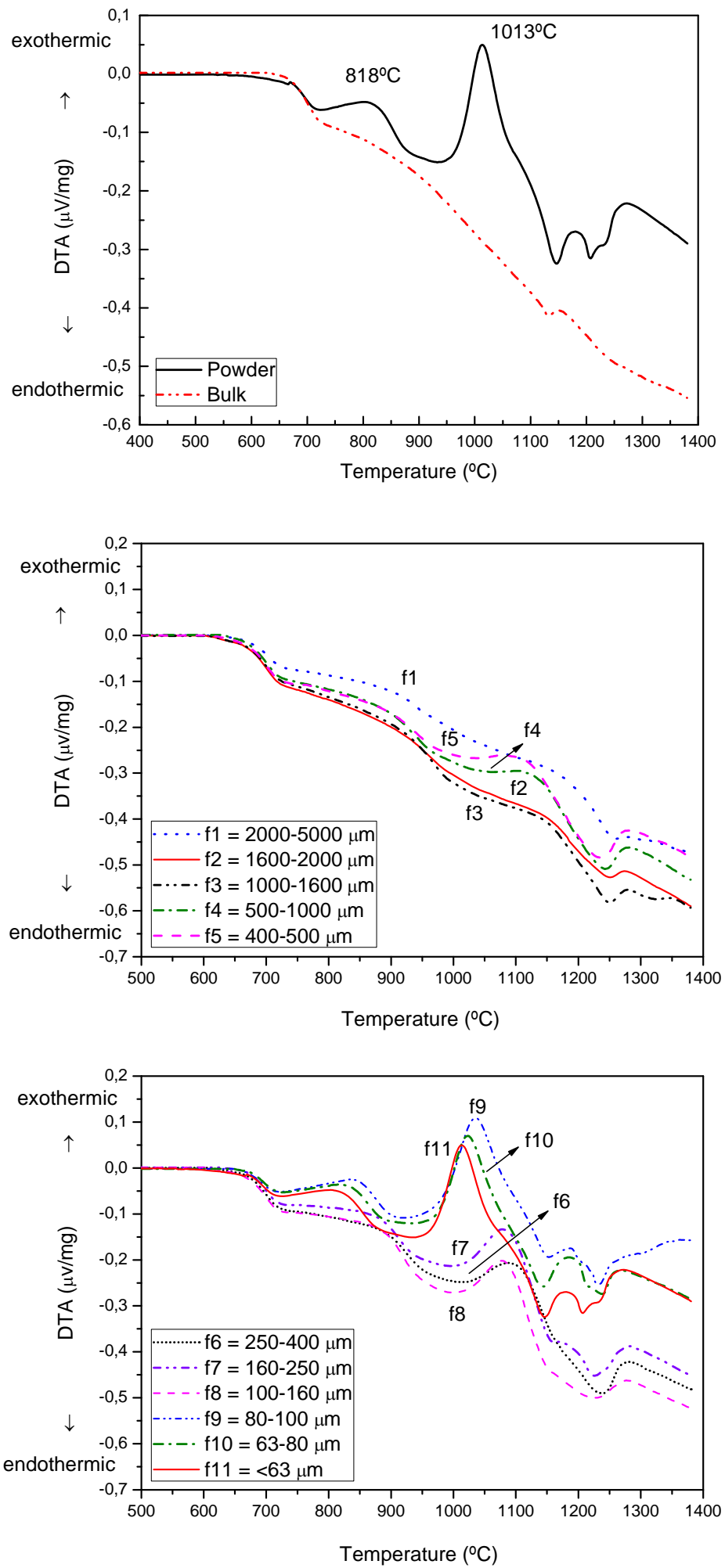

Figure 6 DTA curves for bulk and powder glass samples $\left(25^{\circ}-1450^{\circ} \mathrm{C}, 50^{\circ} \mathrm{C}\right.$ min-1): (6a) powder (f1 1) and bulk, (6b) f1-f5, (6c) f6-f11. 
F.A. López, M.I. Martín, F.J. Alguacil, J.Ma. Rincón, T.A. Centeno, M. Romero. Thermolysis of fibreglass polyester composite and reutilisation of the glass fibre residue to obtain a glass-ceramic material.

Journal of Analytical and Applied Pyrolysis, 93 (2012) 104-112; DOI: 10.1016/j.jaap.2011.10.003

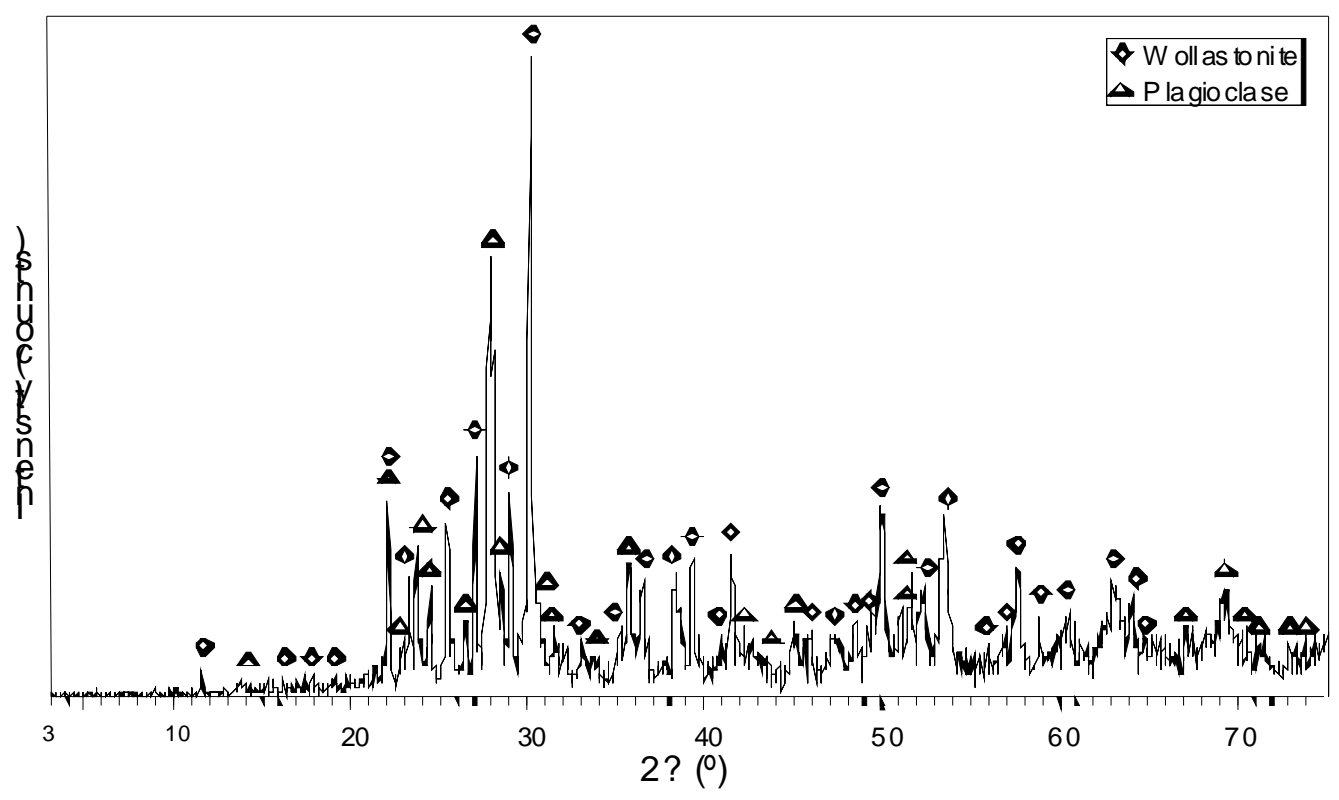

Figure $7 \mathrm{X}$-ray diffraction patterns for the glass-ceramic material produced by thermal treatment of the powder glass $\left(\mathrm{T}=1013^{\circ} \mathrm{C}, \mathrm{t}=60 \mathrm{~min}\right)$.
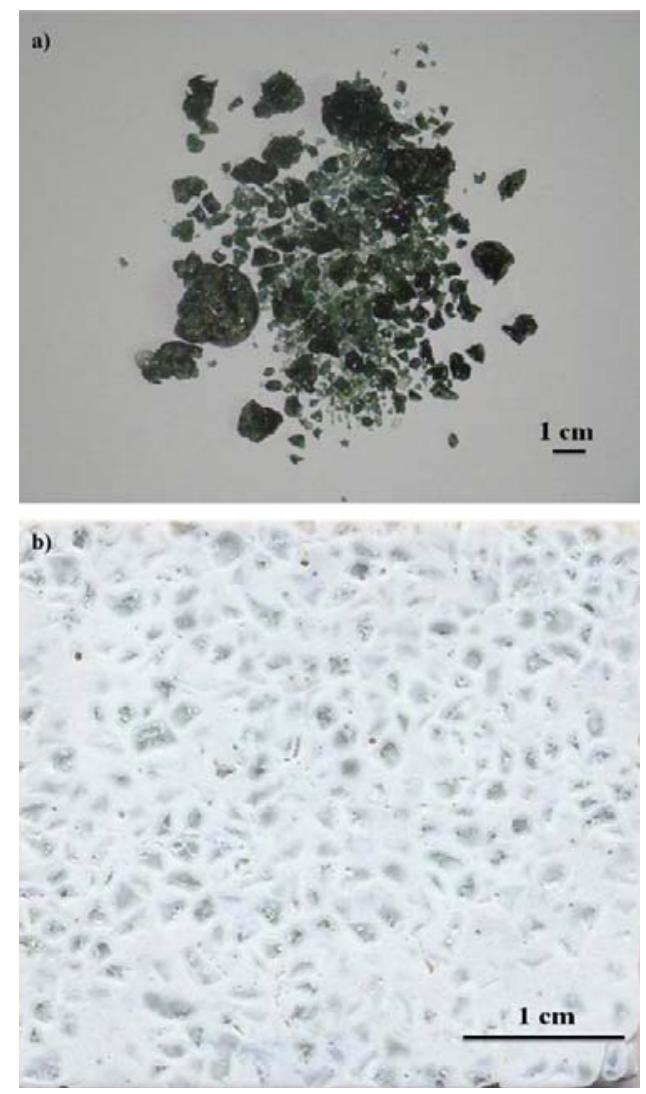

Figure $7 \mathrm{X}$-ray diffraction patterns for the glass-ceramic material produced by thermal treatment of the powder glass $\left(\mathrm{T}=1013^{\circ} \mathrm{C}, \mathrm{t}=60 \mathrm{~min}\right)$. 
F.A. López, M.I. Martín, F.J. Alguacil, J.Ma. Rincón, T.A. Centeno, M. Romero. Thermolysis of fibreglass polyester composite and reutilisation of the glass fibre residue to obtain a glass-ceramic material.

Journal of Analytical and Applied Pyrolysis, 93 (2012) 104-112; DOI: 10.1016/j.jaap.2011.10.003

A study to optimise the particle size mixture is currently underway. The main goal is to tailor the firing process to the conventional fast-firing schedule used in ceramic tile manufacture. The technological properties of these glass-ceramic tiles will also be determined to establish the feasibility of their use as ceramic building materials.

\section{CONCLUSIONS}

This laboratory-scale study suggests that thermolysis is a highly suitable method for recovering valuable products and energy from PFG. The results allow the following conclusions to be drawn:

(1) The thermolysis of the present PFG resulted in $68 \mathrm{wt} \%$ solid residue; the liquid (oil) and gas fractions accounted for $24 \mathrm{wt} \%$ and $8.0 \mathrm{wt} \%$ respectively.

(2) The oil fraction is a complex mixture of $\mathrm{C}_{5}-\mathrm{C}_{21}$ compounds, basically of aromatic structure $(\approx 84 \%)$, plus a high content of oxygenated species $(\approx 16 \%)$. The oil mostly consists of styrene $(\approx 27 \%)$. Other products such as toluene, ethylbenzene, $\alpha$-methyl styrene, 3-butynil benzene, benzoic acid and 1,2-benzenedicarboxylic acid anhydride (anhydride of o-phthalic acid) are also present. The GCV of the oil, $33.9 \mathrm{MJ} \mathrm{kg}^{-1}$, is similar to that of a fuel oil. Some $50 \%$ of the liquid volume has a boiling point between $70^{\circ}$ and $194^{\circ} \mathrm{C}$, which falls into the range of commercial petroleum.

(3) The gas produced was mostly $\mathrm{CO}_{2}$ and $\mathrm{CO}$; the hydrocarbon fraction made up $<10$ vol\%. The gross calorific value of the gas was low, at about $26 \mathrm{MJ} \mathrm{Nm}^{-3}$.

(4) The solid residue consisted of 97 wt.\% glass fibre and 3 wt.\% carbonaceous material. The glass fibre was successfully recycled by a vitrification process. Size fractions of $>1000 \mu \mathrm{m}$ showed low glass-ceramic-forming ability. The crystalline phases identified in the glass-ceramic material obtained from the finest particle fraction $(\mathrm{f} 11 ;<63 \mu \mathrm{m})$ were wollastonite and plagioclase s.s. 
F.A. López, M.I. Martín, F.J. Alguacil, J.Ma. Rincón, T.A. Centeno, M. Romero. Thermolysis of fibreglass polyester composite and reutilisation of the glass fibre residue to obtain a glass-ceramic material.

Journal of Analytical and Applied Pyrolysis, 93 (2012) 104-112; DOI: 10.1016/j.jaap.2011.10.003

(5) Compact glass-ceramic tiles can be produced from the powder glass via sinteringcrystallisation. By varying the relative percentage of the different particle size fractions, tiles with different aesthetic qualities might be designed.

(6) The novel thermolytic and vitrification processes described in this work hold promise for recycling fibreglass-reinforced composite materials. The SMC and BMC composites, which contain filler, mainlyCaCO3, can also be treated by this process. These fillers should not be separated from the fiberglass. $\mathrm{CaCO}_{3}$ is beneficial because it is a common component in the formation of glass.

\section{ACKNOWLEDGMENTS}

Dr. M.I. Martín expresses her gratitude to the Spanish National Research Council (CSIC) for her contract through the JAE Program (JAEDoc-08-00032), co-financed by the European Social Fund. This work was carried out with the financial support of ENRECO $2000 \mathrm{Ltd}$.

\section{REFERENCES}

[1] Composites Europe 2010. www.composites-europe.com

[2] R. De Rosa, E. Telfeyan, G. Gaustad and S. Mayes, Strength and microscopic investigation of unsaturated polyester BMC reinforced with SMC-recyclate, J. Thermoplast. Compos. Mater. 18(4) (2005) 333-349.

[3] S.J. Pickering, Recycling technologies for thermoset composite materials-current status, Composites Part A 7 (2006) 1206-1215.

[4] T. Inot, T.Yokoi, K.I. Sekiyama, N. Kawamura, Y. Mishima, SMC Recycling Technology, J. Thermoplast. Compos. Mater. 7(1) (1994) 42-55.

[5] A.K. Bledzki, K. Goracy, The use of recycled fiber composites as reinforcement for thermosets, Mech. Compos. Mater. 29(4) (1993) 352-356.

[6] B.Sims, C.A.Booth, Process for separating fibers from composite materials. International Patent WO 93/05883, granted to Phoenix Fiberglass, Inc. 1993. 
F.A. López, M.I. Martín, F.J. Alguacil, J.Ma. Rincón, T.A. Centeno, M. Romero. Thermolysis of fibreglass polyester composite and reutilisation of the glass fibre residue to obtain a glass-ceramic material.

Journal of Analytical and Applied Pyrolysis, 93 (2012) 104-112; DOI: 10.1016/j.jaap.2011.10.003

[7] S.J. Pickering, Benson M., Recovery of materials and energy from thermosetting plastics. Proc. Sixth European Composite Materials Conference, Recycling Concepts and Procedures. Bordeaux, France, September 1993, European Association for Composite Materials, pp. 41-46.

[8] A.A. Garforth, S.Ali, J.Hernández-Martinez, A.Akah, Feedstock recycling of polymer wastes. Curr. Opin. Solid State Mater. Sci. 8 (2005) 419-425.

[9] E-Schmildl, Recycling of fibre-reinforced plastics. International EPTA World Poltrusion Conference. Barcelona, 8-10 April 2010.

[10] E. Schmidl, S. Hinrichs, Method for disposing glass-fiber-reinforced components such as rotor blades of wind turbines with a main body made of fiber-reinforced plastics, comprises supplying the rotor blades to a clinker production process as an alternative fuel more options. Patent Number: WO2010148418-A1.HOLCIM TECHNOLOGY LTD, 2010.

[11] S.J., Evans, P.J., Haines, G.A. Skinner, Pyrolysis-gas-chromatographic study of a series of polyester thermosets, J Anal. Appl. Pyrolysis 55 (2000) 13-28.

[12] A. Torres, I. de Marco, B.M. Caballero, M.F. Laresgoiti, J.A. Legarreta, M.A. Cabrero, A. González, M.J. Chomón, K. Gondra, Recycling by pyrolysis of thermoset composites: characteristics of the liquid and gaseous fuels obtained, Fuel 79(8) (2000) 897-902.

[13] P.T. Williams, A. Cunliffe, N. Jones, Recovery of value-added products from the pyrolytic recycling of glass-fibre-reinforced composite plastic waste, J. Energ. Inst. 78(2) (2005) 51-61.

[14] X.J. Guo, Y.F. Zhang, An Experimental study on recycling waste printed circuit boards with pyrolysis technique. ITESS: 2008, Proceedings of International Conference on Information Technology and Environmental System Sciences, PT 1, 316-321, Henan Polytechn. Univ., Jiaozuo, China, May 15-17 2008.

[15] F.A. López, T.A. Centeno, F.J. Alguacil, B. Lobato, Distillation of granulated scrap tires in a pilot plant, J. Hazard. Mater. 190 (2011) 285-292.

[16] Y. Zheng, Z, Shen, S. Ma, C. Cai, X. Zhao, Y. Xing, A novel approach to recycling of glass fibers from nonmetal materials of waste printed circuit boards, J. Hazard. Mater. 170 (2009) 978-982.

[17] S.J. Pickering, R.M. Kelly, J.R. Kennerley, C.D. Rudd, A fluidized bed process for the recovery of glass fires from scrap thermoset composites, Compos. Sci. Technol.60 (2000) 509523.

[18] H.L.H. Yip, S.J. Pickering, C.D. Rudd, Characterisation of carbon fibers recycled from scrap composites using fluidized bed process, Plast. Rubber Compos. 31(6) (2002) 278-282.

[19] K.H. Wong, S.J. Pickering, C.D. Rudd, Recycled carbon fiber reinforced polymer composite for electromagnetic interference shielding, Composite Part A 41 (2010) 693-702

[20] H. Winter, H.A.M. Mostert, P.J.H.M. Smeets, G. Pass, Recycling of sheet-molding compounds by chemical routes, J. Appl. Polym. Sci. 57(11) (1995) 1409-1417. 
F.A. López, M.I. Martín, F.J. Alguacil, J.Ma. Rincón, T.A. Centeno, M. Romero. Thermolysis of fibreglass polyester composite and reutilisation of the glass fibre residue to obtain a glass-ceramic material.

Journal of Analytical and Applied Pyrolysis, 93 (2012) 104-112; DOI: 10.1016/j.jaap.2011.10.003

[21] W. Mormann, P. Frank, Supercritical ammonia for recycling of thermoset polymers, Macromol. Symposia 242 (2006) 165-173.

[22] T. Iwaya, S. Tokuno, M. Sasaki, M. Goto, K. Shibata, Recycling of fiber reinforced plastics using depolymerization by solvothermal reaction with catalyst, J. Mater. Sci. 43 (2008) 24522456.

[23] G. Jie, L. Ying-Shun, L., Mai-Xi, Product characterization of waste printed circuit board by pyrolysis, J. Anal. Appl. Pyrolysis 83 (2008) 185-189.

[24] A. Torres, I. de Marco, B.M. Caballero, M.F. Laresgoiti, G. Kondra, Recycling of the solid residue obtained from the pyrolysis of fiberglass polyester sheet molding compound, Adv. Polymer Tech. 28(2) (2009) 141-149.

[25] Manfredini, T., Pellacani, G.C. and Rincón, J.Ma., Glass-ceramic materials fundamentals and applications, Ed. Mucchi Editore, Módena, Italy, 1997.

[26] Y. Shih, R. Jeng, K. Wei, Carbon black containing interpenetrating polymer networks based on saturated polyester/epoxy III: thermal and pyrolysis analysis, J. Anal. Appl. Pyrolysis 70 (2003) 129-142.

[27] R. Xiao, M.Zhang, B.Jin and Y.Huang, High-temperature air/steam-blown gasification of coal in a pressurized spout-fluid bed, Energy Fuels 20 (2006) 715-729.

[28] S.J. Evans, P.J. Haines, G.A. Skinner, The effects of structure on the thermal degradation of polyester resins, Thermoch. Acta 278 (1996) 77-89.

[29] S.J. Evans, P.J. Haines, G.A. Skinner, The thermal degradation of polyester resins II. The effects of cure and fillers on degradation, Thermoch. Acta 291 (1997) 43-49.

[30] E. Kandare, B.K. Kandola, D. Price, S. Nazaré, R.A. Horrocks, Study of the thermal decomposition of flame-retarded unsaturated polyester resin by thermogravimetric analysis and Py-GC/MS, Pol. Degrad. Stab. 93(11) (2008) 1996-2006.

[31] L. Tibiletti, C. Longuet, L. Ferry, P. Coutelen, A. Mas, J.J. Robin, J.M. López-Cuesta, Thermal degradation and fire behavior of unsaturated polyester filled with metallic oxides, Pol. Degrad. Stab. 96 (2011) 67-75.

[32] E. Kicko-Walczak, Kinetics of thermal decomposition of unsaturated polyester resin with reduced flammability, J. Appl. Polym. Sci. 88 (2003) 2851-2857.

[33] R.Bansai and J. Mittal, Thermal stability and degradation studies of polyester resin. J. Appl. Polym. Sci. 37 (1989) 1901-1908.

[34] S. Mirmiran, H. Pakdel, C. Roy, Characterization of used tire vacuum pyrolysis oil: Nitrogenous compounds from the naphtha fraction, J. Anal. Appl. Pyrolysis 22 (1992) 205-215.

[35] B. Benallal, C. Roy, H. Pakdel, S. Chabot, M.A. Poirier, Characterization of pyrolytic light naphtha from vacuum pyrolysis of used tyres comparison with petroleum naphtha, Fuel 74(1) (1995) 1589-1594. 
F.A. López, M.I. Martín, F.J. Alguacil, J.Ma. Rincón, T.A. Centeno, M. Romero. Thermolysis of fibreglass polyester composite and reutilisation of the glass fibre residue to obtain a glass-ceramic material.

Journal of Analytical and Applied Pyrolysis, 93 (2012) 104-112; DOI: 10.1016/j.jaap.2011.10.003

[36] A. Torres, I. de Marco, B. M. Caballero, M. F. Laresgoiti, M.A. Cabrero and M. J. Chomón, GC-MS analysis of the liquid products obtained in the pyrolysis of fibre-glass polyester sheet moulding compound, J. Anal. Appl. Pyrolysis, 58-59 (2000) 189-203.

[37] J.Hiltz, Pyrolysis-gas chromatography/mass spectrometry identification of styrene crosslinked polyester and vinyl ester resins, J. Anal. Appl. Pyrolysis 22 (1991) 113-128.

[38] A.M. Cunliffe, P.T. Williams, Characterization of products from the recycling of glass fiber reinforced polyester waste by pyrolysis, Fuel 82 (2003) 2223-2230.

[39] M. Romero, M. Kovacova, J.Ma. Rincón, Effect of particle size on kinetics crystallization of an iron-rich glass, J. Mater. Sci. 43 (2008) 4135-4142.

[40] Ma .S. Hernández-Crespo, J.Ma. Rincón, M. Romero, Nucleation and crystal growth of glasses produced by a generic plasma arc-process, J. Eur. Ceram. Soc. 26(9) (2006) 1679-1685.

[41] S. Teixeira, J.Ma. Rincón, M. Romero, Crystallization of $\mathrm{SiO}_{2}-\mathrm{CaO}-\mathrm{Na}_{2} \mathrm{O}$ glass using sugarcane bagasse ash (SCBA) as silica source, J. Amer. Ceram. Soc. 93 (2010) 450-455.

[42] M.I. Martín, J.Ma. Rincón, M. Romero, F. Andreola, L. Barbieri, F. Bondioli y I. Lancellotti, Materiales vitrocerámicos del sistema $\mathrm{MgO}-\mathrm{Al}_{2} \mathrm{O}_{3}-\mathrm{SiO}_{2}$ a partir de ceniza de cáscara de arroz, Bol. Soc. Esp. Ceram.Vidr. 50(4) (2011) 201-206. 